\title{
Customer segmentation: The concepts of trust, commitment and relationships
}

Received (in revised form): 10th September, 2007

\section{Bertil Hultén}

is Assistant Professor of Marketing at Baltic Business School (BBS) based at Kalmar University, Sweden. His areas of research interest are in relationship marketing and retailing, especially $\mathrm{B} 2 \mathrm{C}$ relationships. He has published a number of scientific research papers and research reports. $\mathrm{He}$ also has academic work experience with other universities in Scandinavia and North Africa.

\section{Keywords customer segmentation, trust, commitment, relationships}

\begin{abstract}
Few studies have emphasised a service firm's customer base for segmentation purposes in identifying weak or strong relationships in a consumer mass marketing context of services. The research contributes to an understanding of how high or low levels of trust and of commitment can be used to differentiate customers in terms of active, use the services regularly, and passive, use the services only occasionally. The empirical study was based on a customer sample of a Swedish processing laboratory using direct marketing (DM) and on-line activities as marketing tools. A mail survey $(n=4,130)$ was used and multiple items were applied to seven constructs. A $t$-test for an independent sample was used to assess whether the two customer groups were statistically different. The results are that active customers differ significantly on 22 of the 27 measured items. Consequently, active customers are more relational, with high levels of trust and of commitment, and passive customers are less relational. A theoretical and managerial implication is to use the chosen constructs (ie indicators) as segmentation variables of a firm's customer base in developing strategies for long-term customer relationships.

Journal of Targeting, Measurement and Analysis for Marketing (2007) 15, 256-269. doi:10.1057/palgrave.jt.5750051
\end{abstract}

\section{INTRODUCTION}

According to the relationship marketing management school, ${ }^{1}$ the growing importance of customers and a customer-centric view underlines the need for a better understanding of how markets and business-to-consumer (B2C) relationships are developed, maintained and structured. An important concept in this regard is that it is more profitable for a firm to establish long-term customer relationships than to adopt a short-term transaction-oriented approach. ${ }^{2}$ In RM theory, generally trust and commitment seem to be inseparable, stating that if both are not in

Correspondence: Bertil Hultén, Baltic Business School, Kalmar University, Kalmar 391 82, Sweden.

Tel: + 46480497154 ;

Fax: + 46480497110 ;

E-mail: bertil.hulten@hik.se place a relationship is more likely to be a loose and unstable arrangement.

In this study, the concepts of trust, commitment and relationships are applied in a consumer mass marketing context of services in order to analyse the relational orientation of a firm's customer base. The aim of the empirical study is to identify the relationship character of the customer base of a service firm in terms of weak and strong relationships. On the surface it might often seem that ongoing relationships exist and develop over time but it is sometimes unclear whether they are built upon low or high levels of trust and of commitment.

In general, the terms 'relationship marketing' and 'customer relationship management (CRM)' are often treated as interchangeable in the academic literature. ${ }^{3}$ The CRM concept incorporates and integrates all activities within the 
firm, the value chain and the network of firms that create, generate and deliver both customer and firm value through value-creating processes. ${ }^{4}$ Moreover, CRM is related to business and customer strategy, customer experience and knowledge, the use of information and technology, and development of long-term relationships with customers or customer groups. ${ }^{5}$

In a recently published paper, Payne and Frow ${ }^{6}$ have further pointed out that the concept of CRM should even go beyond a customer focus: 'it requires a cross-functional integration of processes, people, operations, and marketing capabilities that is enabled through information, technology, and applications' (ibid., p. 168).

Information technology has been used to manage customer relationships in establishing individual one-to-one relationships on a mass customisation basis. ${ }^{7}$ The idea of mass customisation based on retaining the economic advantages of mass production has been to consider each customer as a segment in order to customise products and services to meet individual needs and requirements.

Through CRM, segmentation can even be applied to smaller segments in the form of 'micro marketing, 8 or 'customer specific marketing' in order to identify the 'gold customers' ${ }^{10}$ As an analytical approach, CRM also deals with the use of such tools as loyalty schemes (or programmes) in collecting and analysing data on individual customers for segmentation purposes.

As a result of this study, a segmentation approach relating to the concepts of trust, commitment and relationships is suggested in order to analyse a firm's customer base.

\section{CONCEPTUAL FRAMEWORK}

In this section, I discuss the conceptual relationship between the concept of segmentation, on the one hand, and the concepts of trust, commitment, relationships and the transactional/ relational continuum, on the other. I discuss the development of the concept of segmentation, in a CRM perspective, with an emphasis on its applicability and usefulness. I also analyse the applicability of such concepts as trust, commitment and relationships for segmentation purposes. I subsequently define the transactional/ relational continuum as a basis for customer segmentation and discuss its contribution to the understanding of relationship development in a firm.

Altogether, the conceptual framework underlines the option to use a firm's customer base as a ground for segmentation in terms of strong or weak relationships in establishing and maintaining long-term relationships.

\section{The two-dimensional concept of segmentation}

Market segmentation is one of the most fundamental marketing theory concepts, in terms of matching supply with demand and constituting an important component of a firm's marketing strategy. ${ }^{11}$

The concept of segmentation was originally related to economic theory, stating that competition is imperfect and that either the lack of homogeneity or close similarity among products is quite evident. ${ }^{12}$ For this reason, market segmentation and product differentiation were seen as consistent with the framework of imperfect competition. The segmentation concept was originally developed by American manufacturers in order to move away from mass marketing in consumer markets in terms of all being the same.

The segmentation concept can be applied to an investigation of how consumers perceive market structures. The aim should also be to learn more about how consumers perceive the various different brands or products with respect to their strengths, weaknesses, the satisfaction they provide and so on. Finally, it should be possible to integrate and apply the findings strategically in developing and implementing a marketing mix that creates a market position in the minds of the consumers. In a market-oriented strategy, target marketing is distinguished from mass marketing in terms of targeting specific customers in a particular segment.

Some researchers have argued that there is a lack of a generally acceptable, validated means of identifying and segmenting markets. ${ }^{13}$ On the other hand, four types of segmentation have 
emerged as the most well known in B2C markets. These are geographic, demographic, psychographic and behaviouristic segmentation. Also, other criteria have been used, including product usage rates, lifestyle and brand personality.

Doyle ${ }^{14}$ questioned the effectiveness of market segmentation, arguing that it has proven to be particularly vulnerable, being a somewhat superficial tool in an RM perspective. Also, Gordon $^{15}$ stated that it is far more difficult than ever before to categorise buyers, particularly when using traditional segmentation criteria. The main reason is the increasing complexity of buyer behaviour, leading Gordon to claim that the only meaningful categorisation is 'actual' in contrast to 'speculative' buyer behaviour.

An alternative interpretation would seem to be that marketers should try to identify individual customers in the customer base of a firm in existing and ongoing relationships. The objective should be to structure the relationships in new and better ways.

Moreover, in contrast to market segmentation, customer segmentation is related to a classification of potential and current customers, based on their market reactions. It has also been suggested that in view of RM, the traditional segmentation criteria have to be expanded. ${ }^{16}$ This is one of the important arguments behind this study.

The development of the segmentation concept during the last decades entails a shift from market segmentation to customer segmentation. The concept has become two dimensional, with an emphasis on market segmentation at the business strategy level and customer segmentation at the customer strategy level in a CRM perspective. Therefore, the concept of segmentation corresponds to trust, commitment and relationships as well as the transactional/relational continuum in terms of relationship development over time.

\section{Trust, commitment and relationships}

Customer strategy often considers issues relating to the potential and existing customer base, as well as to decision-making about segmentation. It entails deciding about appropriate forms of segmentation and levels of subdivision, sometimes called segment granularity. These decisions are often related to what segmentation approach, for example macro, micro or one to one, a firm should choose so as to ensure a fit between the customer base and the market.

Another issue that is closely related to segmentation procedures is whether to identify the 'good' or 'bad' customers and to consider retention and valuation accordingly. ${ }^{17,18}$ Many firms can surely benefit from discovering which customers are the 'best' and differentiating between them in terms of loyalty and profitability. ${ }^{19}$

For this reason, it is also suggested that in order to build and establish relationships the concepts of trust and of commitment are to be seen as prerequisites. On the other hand, it is also stated that it is possible to have relationships with the absence of commitment and a customer seems to be 'trapped' rather than committed. ${ }^{20}$

Trust as a concept is often related to a customer's willingness to rely upon a firm's actions and behaviour in the future. The concept represents relationship quality in the sense that it helps to reduce uncertainty in complex human relationships. ${ }^{21}$ Moreover, trust in itself is not a behaviour; instead, it can result from such activities like cooperation or a business deal. Often, trust is seen as an important element and foundation for interpersonal relationships as well as a ground for stability in organisational relationships.

Commitment as a concept is mostly related to a relationship where two parties will be loyal and will show stability to each other. Often, there is a wish to maintain a relationship because of activities and investments that link a buyer and a seller together. It may take some time before a commitment can be made, which might imply a more mature relationship. A common opinion is that customer commitment only relates to a seller or a relationship with a seller and no other things. It is also suggested that a high commitment level might be seen as an important emotional barrier in switching behaviour.

Relationship as a concept is often related to the types of relationships that might exist between 
a buyer and a seller. ${ }^{22}$ Organisational relationships between a seller and a buyer exist independent of interpersonal relationships between an employee and a customer in contrast to social relationships, which always occur between individuals. In this sense, organisational relationships are also linked to concepts such as reputation and trustworthiness, especially when nonpersonal relationships exist between a seller and a buyer.

\section{The transactional/relational continuum}

A fundamental premise in relationship marketing theory is to consider relationships as a continuum from transactional at one end to relational orientations at the other end proposed by Dwyer et al. ${ }^{23} \mathrm{~A}$ firm, or indeed any other organisation, should take into consideration and depend on the customer's view of a relationship as either transactional or relational in order to decide how exactly to operate in this context. For this reason, a firm (or any other organisation) should try to determine the location of its customers on a continuum from transactional to collaborative exchanges. $^{24}$

A basic hypothesis in RM theory is that a firm needs transactional as well as relational strategies according to the transactional/relational continuum by Brodie et al. ${ }^{25}$ As a result, a firm might simultaneously pursue the use of both transactional and relational marketing approaches because of different customer viewpoints.

Both the industrial marketing and relationship marketing theory suggest that individual customers can be identified in different stages (or phases) of relationship development. The various stages demonstrate how buyers and sellers interact with each other in terms of relational development. The proposed models of interaction illustrate the frequent emphasis on acquisition of new customers ending up with sale as transaction marketing and the emphasis on long-term relationships as relationship marketing.

The above-mentioned theoretical, descriptive models of how two parties could relate to one another, have seldom been empirically validated.
A weakness of these models is that they are based more on a logical, theoretical reasoning of what could characterise the different stages of relationship development than on empirical investigation and findings.

In contrast to these models, the notion of the transactional/relational continuum can be related to relationship development over time. In the continuum, a transactional approach in B2C markets and a more relational approach in business-to-business markets have been suggested. Also, in B2C markets, it is likely that customers actively seek a relationship, but it is probable that suppliers will manage the interaction in the mutual interest of both parties. The relationships between buyers and sellers in consumer markets are often considered to be much looser and characterised by fewer and weaker bonds than in business-to-business markets.

\section{HYPOTHESES}

It is generally accepted that the concepts of trust and of commitment determine whether a relationship is functional (transactional) or relational in terms of partnerships. This means that the degree of trust and of commitment indicates whether customers are real partners or just interested in a single or repeat transaction. ${ }^{26}$ For customers with strong relationships (relational orientation), where there are high levels of trust and of commitment, it has also been suggested that trust and commitment are vitally important in determining attitudes and belief structures.

In the present empirical study, the following hypotheses are tested. They relate to weak and strong relationships in the context of the degree of trust and of commitment:

\section{$\mathbf{H}_{1}$ : Customers with a weak relational orientation yield a positive relationship between low levels of trust and of commitment.}

Hypothesis 1 is built around the assumption that there exists a positive relationship between low levels of trust and of commitment indicating weak relationships. Following the transactional/relational 
continuum, it supports a transactional orientation of a firm's customer base.

$\mathbf{H}_{2}$ : Customers with a strong relational orientation yield a positive relationship between high levels of trust and of commitment.

Hypothesis 2 is built around the assumption that there exists a positive relationship between high levels of trust and of commitment indicating strong relationships. Following the transactional/ relational continuum, it supports a relational orientation of a firm's customer base.

\section{RESEARCH DESIGN}

\section{The context of the study}

As one of the few empirical studies in the area, Garbarino and Johnson ${ }^{27}$ investigated the transactional/relational continuum in a consumer market service context in terms of weak (transactional) or strong (relational) relationships. The authors investigated how different customer groups in a consumer market context may vary in responding to transactional or relational marketing in the context of a professional, nonprofit repertory theater company in New York. The study provides support for the transactional/relational continuum by stating that there are large differences in trust and commitment on the part of current subscribers, compared to that of occasional subscribers and individual ticket buyers.

In the study with which this present paper is concerned, the company also provides customers with services in a consumer market context. The service is that of developing and printing both traditional and digital photographs. The firm also offers cameras, equipment and other services related to photographing and processing. The marketing strategy is based on DM, on-line activities and customer service without any store location or distribution network. As most of the interactions between the company and customers are non-personal, the evaluation of the brand and the services are related primarily to functional and technical requirements.
The main difference between the two studies concerns the chosen service context in terms of type of organisational relationship and social interaction. In Garbarino and Johnson's study, the service context is built upon interpersonal relationships between the actors, physical facilities and audience (customers) in the theatre. In this study, however, the service context revolves around nonpersonal relationships among the company, its brand and the customers.

\section{Sample and data collection procedure}

The data collection was based on a customer sample of 4,130 customers drawn from the customer base of a Swedish-based processing laboratory. The company had identified two groups of customers: active customers, who used the services regularly, and passive customers, who used the services only occasionally.

The customer base consists of customers from almost all cities and regions in Sweden. In order to find a sample that corresponds to the Swedish population structure in terms of an equal distribution between men and women, official Swedish government statistics were used. It was evident from the customer base that women constituted a large customer group of the company, and hence it was important to ensure that women were equally represented in the random sample.

It was found that in two regions, Jönköping and Norrköping, the distribution was nearly fiftyfifty between men (49.8 per cent) and women (50.2 per cent). Consequently, these two regions, which cover both urban and rural areas, were chosen for the study. A random sample was drawn from the company's customer database, consisting of men and women in both an active customer group $(1,997)$ and a passive customer group $(2,133)$. In the active group, 1,083 customers were located in Jönköping and 914 in Norrköping. In the passive group, 1,158 were from Jönköping and 975 were from Norrköping.

A mail survey was used for the data collection and two reminders were sent out during a threeweek period. The final response rate was 54 per cent, corresponding to 2,241, customers with 
Table 1: Final sample characteristics

\begin{tabular}{lll}
\hline Customers & Numbers & \\
\hline Response rate & 2,241 & \\
Female & 1,310 & 1,812 \\
Male & 502 & \\
& & \\
Age & & \\
-17 & 42 & \\
$18-24$ & 279 & 1,812 \\
$25-44$ & 944 & \\
$45-64$ & 426 & 1,812 \\
$65-$ & 121 & \\
City & 1,183 & \\
Countryside & 629 & \\
\hline
\end{tabular}

65 per cent of active customers and 47 per cent of passive customers (see Table 1). It was evident that the final sample was only slightly more weighted towards women than men, which justified the sampling procedure.

\section{Measuring the constructs}

In order to test the two hypotheses, four endogenous constructs were adapted from Garbarino and Johnson and measured: overall satisfaction, trust, commitment and future intentions. In addition, three exogenous constructs were adapted and measured: brand satisfaction, brand familiarity and brand attitude. Multiple items were applied to seven constructs (see Table 2). The items were derived both from the relevant literature and interviews with representatives of the company.

The construct overall satisfaction is measured from the customer perspective. It is defined as a cumulative construct comprising satisfaction with specific components like products and services of an organisation and satisfaction with various aspects of a firm such as facilities, people or technology. ${ }^{28}$ The construct is based on 'an overall evaluation of the total purchase and experience with a good or a service over time' defined by Anderson et al. ${ }^{29}$ The component attitudes has been linked to different aspects of the service offering as expressed in items A1-A3 (see Table 2).

The construct trust as a social norm is defined as confidence, trustworthiness and reliability in building and establishing successful relationships. Trustworthiness and trust are often seen as mutual as 'the trustworthiness of one party results in the other party trusting that party' by Jansson (op. cit., p. 211). ${ }^{30}$ Garbarino and Johnson define trust as 'customer confidence in the quality and reliability of the services offered by the organization', thus highlighting the importance of the construct. In the present study, organisational trust was measured using a five-item scale: items B1-B5.

The construct commitment is defined as the relative propensity of a customer to engage in and maintain a relationship. ${ }^{31}$ Although central to relationship marketing, there is no general agreement on the nature of the construct. Nonetheless, the construct is generally defined in terms of the affective and continuance components that might affect a single relationship. It was measured using a five-item scale: items C1-C5.

The construct future intentions is defined as a customer's desire to leave or stay with an organisation or the likelihood of doing so. ${ }^{32}$ It was measured using a four-item scale: items D1-D4.

The construct brand satisfaction is defined as satisfaction with the company. It was measured using a four-item scale following items E1-E3.

The construct brand familiarity is defined as the degree to which customers know the brand and have clear perceptions of its characteristics. It was measured using a two-item scale: items F1-F2.

The construct brand attitudes is defined as attitudes towards the company. It was measured using a five-item scale: items G1-G5.

The scales used to measure the constructs were adapted from Garbarino and Johnson and all scale items are given in Table 2. Overall satisfaction was measured with the conventional semantic differential (SD) scale as well as a comparative item $(\mathrm{Cm})$ in relation to other competitors on seven-point scales ranging from one (much worse) to seven (much better). Other items were measured on five-point Likert-type (Lkt) scales ranging from one (disagree) to five (agree). 


\section{Hultén}

Table 2: Construct, item and scale used for the measures

\begin{tabular}{|c|c|c|c|c|}
\hline Construct & $\mathrm{Me}$ & surement item & Type of s & \\
\hline Overall satisfaction & $\begin{array}{l}\text { A1 } \\
\text { A2 } \\
\text { A3 }\end{array}$ & $\begin{array}{l}\text { How satisfied are you with the company? } \\
\text { How would you rate the company compared to } X ? \\
\text { How would you rate the company compared to } Y \text { ? }\end{array}$ & $\begin{array}{l}-3 \text { to }+3 \\
1 \text { to } 7 \\
1 \text { to } 7\end{array}$ & $\begin{array}{l}\mathrm{SD} \\
\mathrm{Cm} \\
\mathrm{Cm}\end{array}$ \\
\hline Trust & $\begin{array}{l}\text { B1 } \\
\text { B2 } \\
\text { B3 } \\
\text { B4 } \\
\text { B5 }\end{array}$ & $\begin{array}{l}\text { The photo processing always meet my expectations } \\
\text { The company always provides good products/services } \\
\text { I can always rely on the company to deliver what it promises } \\
\text { I have a great confidence in the company } \\
\text { The company rewards its loyal customers }\end{array}$ & $\begin{array}{l}1 \text { to } 5 \\
1 \text { to } 5 \\
1 \text { to } 5 \\
1 \text { to } 5 \\
1 \text { to } 5\end{array}$ & $\begin{array}{l}\text { Lkt } \\
\text { Lkt } \\
\text { Lkt } \\
\text { Lkt } \\
\text { Lkt }\end{array}$ \\
\hline Commitment & $\begin{array}{l}\text { C1 } \\
\text { C2 } \\
\text { C3 } \\
\text { C4 } \\
\text { C5 }\end{array}$ & $\begin{array}{l}\text { I am proud to be a customer of the company } \\
\text { The staff are committed to me as customer } \\
\text { I feel I want to be a customer of the company } \\
\text { I have been a customer for many years } \\
\text { I talk positively about company and recommend it }\end{array}$ & $\begin{array}{l}1 \text { to } 5 \\
1 \text { to } 5 \\
1 \text { to } 5 \\
1 \text { to } 5 \\
1 \text { to } 5\end{array}$ & $\begin{array}{l}\text { Lkt } \\
\text { Lkt } \\
\text { Lkt } \\
\text { Lkt } \\
\text { Lkt }\end{array}$ \\
\hline Future intentions & $\begin{array}{l}\text { D1 } \\
\text { D2 } \\
\text { D3 } \\
\text { D4 }\end{array}$ & $\begin{array}{l}\text { I plan to use the processing service in the future } \\
\text { It should be negative if the relationship couldn't last } \\
\text { I will continue to be a loyal customer } \\
\text { I will continue if I get good products and services }\end{array}$ & $\begin{array}{l}1 \text { to } 5 \\
1 \text { to } 5 \\
1 \text { to } 5 \\
1 \text { to } 5\end{array}$ & $\begin{array}{l}\text { Lkt } \\
\text { Lkt } \\
\text { Lkt } \\
\text { Lkt }\end{array}$ \\
\hline $\begin{array}{l}\text { Exogenous constructs } \\
\text { Brand satisfaction }\end{array}$ & $\begin{array}{l}\text { E1 } \\
\text { E2 } \\
\text { E3 }\end{array}$ & $\begin{array}{l}\text { How would you rate your overall satisfaction with the film } \\
\text { processing of the company? } \\
\text { The quality of processing is high } \\
\text { Photo deliveries are reliable }\end{array}$ & $\begin{array}{l}-3 \text { to }+3 \\
1 \text { to } 5 \\
1 \text { to } 5\end{array}$ & $\begin{array}{l}\text { SD } \\
\text { Lkt } \\
\text { Lkt }\end{array}$ \\
\hline Brand familiarity & $\begin{array}{l}\mathrm{F} 1 \\
\mathrm{~F} 2\end{array}$ & $\begin{array}{l}\text { I enjoy my personal contact with the company } \\
\text { Special price offers are essential in my choosing the company }\end{array}$ & $\begin{array}{l}1 \text { to } 5 \\
1 \text { to } 5\end{array}$ & $\begin{array}{l}\text { Lkt } \\
\text { Lkt }\end{array}$ \\
\hline Brand attitudes & $\begin{array}{l}\text { G1 } \\
\text { G2 } \\
\text { G3 } \\
\text { G4 } \\
\text { G5 }\end{array}$ & $\begin{array}{l}\text { In general, how satisfied are you with the offerings? } \\
\text { The company does high quality photo processing } \\
\text { I like the design of the photo bags } \\
\text { The company has a useful picture guarantee } \\
\text { The company provides fast and reliable deliveries }\end{array}$ & $\begin{array}{l}-3 \text { to }+3 \\
1 \text { to } 5 \\
1 \text { to } 5 \\
1 \text { to } 5 \\
1 \text { to } 5\end{array}$ & $\begin{array}{l}\text { SD } \\
\text { Lkt } \\
\text { Lkt } \\
\text { Lkt } \\
\text { Lkt }\end{array}$ \\
\hline
\end{tabular}

\section{Measurement validation}

Initially, I used a confirmatory factor analysis to assess the measurement validity for all constructs (construct validity) in the research framework. The confirmatory factor analysis was based on the methods Principal Component Analysis (PCA) and Varimax with Kaiser Normalisation.

The initial results did not indicate that any items loaded poorly on their respective scales. Consequently, it was not necessary to delete any items. Table 3 shows the results for the constructs, factor loadings and mean scores for each individual item.

A confirmatory factor analysis is often regarded as superior to other, more traditional criteria in terms of scale validation. ${ }^{28}$ From Table 3, it is clear that all items relate strongly to the constructs and are close to one. For each construct (factor), the individual items are highly loaded, exceeding 0.5 . This means that the items are acceptable and reliable measures of the chosen constructs. For this reason, the measurement of the constructs and the resulting indicators allow valid theoretical generalisations to be made.

The correlation coefficients for all the constructs in the study were measured with Pearson's $r$ in order to assess discriminant validity. The point is frequently made that items of different constructs could possibly measure the same thing if they are too highly correlated. Therefore, researchers commonly use a rule of thumb of $r=0.85$ as a cutoff for the assessment of discriminant validity. Table 4 contains a correlation matrix of the constructs. 
Table 3: Confirmatory factor analysis total sample

\begin{tabular}{|c|c|c|c|}
\hline Construct/Factor & Factor loadings & Mean scores & Scale items/indicators \\
\hline Overall satisfaction & 0.812 & 5.84 & How satisfied are you with the company? \\
\hline & $\begin{array}{l}0.901 \\
0.870\end{array}$ & $\begin{array}{l}5.42 \\
5.09\end{array}$ & $\begin{array}{l}\text { How would you rate the company compared to } X ? \\
\text { How would you rate the company compared to } Y \text { ? }\end{array}$ \\
\hline Trust & $\begin{array}{l}0.777 \\
0.735 \\
0.798 \\
0.865 \\
0.740\end{array}$ & $\begin{array}{l}4.17 \\
3.86 \\
4.35 \\
4.26 \\
3.94\end{array}$ & $\begin{array}{l}\text { The photo processing always meet my expectations } \\
\text { The company always provides good products/services } \\
\text { I can always rely on the company to deliver what it promises } \\
\text { I have a great confidence in the company } \\
\text { The company rewards its loyal customers }\end{array}$ \\
\hline Commitment & $\begin{array}{l}0.865 \\
0.801 \\
0.864 \\
0.597 \\
0.776\end{array}$ & $\begin{array}{l}3.62 \\
3.74 \\
4.00 \\
3.68 \\
3.23\end{array}$ & $\begin{array}{l}\text { I am proud to be a customer of the company } \\
\text { The staff are committed to me as customer } \\
\text { I feel I want to be a customer of the company } \\
\text { I have been a customer for many years } \\
\text { I talk positively about company and recommend it }\end{array}$ \\
\hline Future intentions & $\begin{array}{l}0.908 \\
0.842 \\
0.917 \\
0.613\end{array}$ & $\begin{array}{l}4.06 \\
3.59 \\
3.89 \\
4.44\end{array}$ & $\begin{array}{l}\text { I plan to use the processing service in the future } \\
\text { It should be negative if the relationship couldn't last } \\
\text { I will continue to be a loyal customer } \\
\text { I will continue if I get good products and services }\end{array}$ \\
\hline Brand satisfaction & $\begin{array}{l}0.857 \\
0.852 \\
0.724\end{array}$ & $\begin{array}{l}5.85 \\
4.24 \\
4.51\end{array}$ & $\begin{array}{l}\text { How would you rate your overall satisfaction with the film } \\
\text { processing of the company? } \\
\text { The quality of processing is high } \\
\text { Photo deliveries are reliable }\end{array}$ \\
\hline Brand familiarity & $\begin{array}{l}0.802 \\
0.802\end{array}$ & $\begin{array}{l}3.71 \\
3.59\end{array}$ & $\begin{array}{l}\text { I enjoy my personal contact with the company } \\
\text { Special price offers are essential in my choosing the company }\end{array}$ \\
\hline Brand attitudes & $\begin{array}{l}0.739 \\
0.730 \\
0.728 \\
0.718 \\
0.779\end{array}$ & $\begin{array}{l}5.58 \\
3.87 \\
4.15 \\
4.42 \\
4.42\end{array}$ & $\begin{array}{l}\text { In general, how satisfied are you with the offerings? } \\
\text { The company does high-quality photo processing } \\
\text { I like the design of the photo bags } \\
\text { The company has a useful picture guarantee } \\
\text { The company provides fast and reliable deliveries }\end{array}$ \\
\hline
\end{tabular}

Table 4: Correlation matrix total sample

\begin{tabular}{lllllll}
\hline $\begin{array}{l}\text { Overall } \\
\text { satisfaction }\end{array}$ & Trust & Commitment & $\begin{array}{l}\text { Future } \\
\text { intention }\end{array}$ & $\begin{array}{l}\text { Brand } \\
\text { satisfaction }\end{array}$ & $\begin{array}{l}\text { Brand } \\
\text { familiarity }\end{array}$ & Brand attitude \\
\hline 1.00 & 0.727 & 0.728 & 0.686 & 0.647 & 0.559 & 0.696 \\
0.727 & 1.00 & 0.704 & 0.630 & 0.685 & 0.563 & 0.777 \\
0.728 & 0.704 & 1.00 & 0.806 & 0.542 & 0.569 & 0.658 \\
0.686 & 0.630 & 0.806 & 1.00 & 0.536 & 0.525 & 0.626 \\
0.647 & 0.685 & 0.542 & 0.536 & 1.00 & 0.407 & 0.651 \\
0.559 & 0.563 & 0.569 & 0.525 & 0.407 & 1.00 & 0.569 \\
0.696 & 0.777 & 0.658 & 0.626 & 0.651 & 0.569 & 1.00 \\
\hline
\end{tabular}

The interrelationships between the constructs are positive according to Pearson's $r$ and the correlation coefficients are between 0.5 and 1.0, except for brand satisfaction and brand familiarity. Overall, there is a strong correlation between the constructs, but for no construct does the rule-of-thumb value exceed $r=0.85$, indicating that the construct indicators do not measure the same thing.
In order to consider the two hypotheses, the measurement validity for all the constructs (construct validity) was assessed with regard to the two customer groups of active and passive customers. A second confirmatory factor analysis using PCA was also conducted, and the results for the individual construct and the factor loading for each group are presented in Table 5 . 
Table 5: Confirmatory factor analysis for customer groups

\begin{tabular}{|c|c|c|c|}
\hline \multirow[t]{2}{*}{ Construct/Factor } & \multicolumn{2}{|c|}{ Factor loadings } & \multirow[t]{2}{*}{ Scale items/indicators } \\
\hline & Active & Passive & \\
\hline \multirow[t]{3}{*}{ Overall satisfaction } & 0.782 & 0.820 & How satisfied are you with the company? \\
\hline & 0.907 & 0.897 & How would you rate the company compared to $X$ ? \\
\hline & 0.883 & 0.865 & How would you rate the company compared to $Y$ ? \\
\hline \multirow[t]{5}{*}{ Trust } & 0.742 & 0.791 & The photo processing always meet my expectations \\
\hline & 0.743 & 0.730 & The company always provides good products/services \\
\hline & 0.809 & 0.794 & I can always rely on the company to deliver what it promises \\
\hline & 0.860 & 0.866 & I have a great confidence in the company \\
\hline & 0.798 & 0.716 & The company rewards its loyal customers \\
\hline \multirow[t]{5}{*}{ Commitment } & 0.862 & 0.865 & I am proud to be a customer of the company \\
\hline & 0.790 & 0.806 & The staff are committed to me as customer \\
\hline & 0.847 & 0.871 & I feel I want to be a customer of the company \\
\hline & 0.655 & 0.571 & I have been a customer for many years \\
\hline & 0.764 & 0.783 & I talk positively about company and recommend it \\
\hline \multirow[t]{4}{*}{ Future intentions } & 0.904 & 0.909 & I plan to use the processing service in the future \\
\hline & 0.828 & 0.848 & It should be negative if the relationship couldn't last \\
\hline & 0.914 & 0.918 & I will continue to be a loyal customer \\
\hline & 0.615 & 0.607 & I will continue if I get good products and services \\
\hline \multirow[t]{3}{*}{ Brand satisfaction } & 0.863 & 0.855 & $\begin{array}{l}\text { How would you rate your overall satisfaction with the film } \\
\text { processing of the company? }\end{array}$ \\
\hline & 0.853 & 0.851 & The quality of processing is high \\
\hline & 0.760 & 0.706 & Photo deliveries are reliable \\
\hline \multirow[t]{2}{*}{ Brand familiarity } & 0.781 & 0.810 & I enjoy my personal contact with the company \\
\hline & 0.781 & 0.810 & Special price offers are essential in my choosing the company \\
\hline \multirow[t]{5}{*}{ Brand attitudes } & 0.727 & 0.745 & In general, how satisfied are you with the offerings? \\
\hline & 0.702 & 0.740 & The company does high-quality photo processing \\
\hline & 0.688 & 0.742 & I like the design of the photo bags \\
\hline & 0.742 & 0.709 & The company has a useful picture guarantee \\
\hline & 0.771 & 0.781 & The company provides fast and reliable deliveries \\
\hline
\end{tabular}

Here too, all items are highly related to the constructs and are close to one. For each construct, the individual items are highly loaded, exceeding 0.5 , meaning that the items are acceptable and reliable measures of the chosen constructs. Once again, this enables valid theoretical generalisations to be made about the differences between the two customer groups.

A second analysis of the correlation coefficients was also conducted, using Pearson's $r$ to assess discriminant validity. The analysis yielded similar results as in the previous analysis, proving that the items of the constructs do not measure the same thing.

\section{RESULTS}

The premise underlying the research is that there is a difference in the fundamental orientation between customer groups, as expressed in Hypothesis 1 and Hypothesis 2. This refers to either the relational orientation (strong relationship) or the transactional orientation (weak relationship). It was assumed that customers with strong relationships should have high levels of trust and of commitment compared to customers with weak relationships. Table 6 shows that, according to the research results, there is indeed a difference between active customers and passive customers with regard to levels of trust and of commitment.

A $t$-test for an independent sample was used to assess whether the mean scores of the two groups - active customers versus passive customers were statistically different. The $t$-test was deemed appropriate, because the research objective was to 
compare the differences between the mean scores of the two groups, relative to the spread or variability of the respective scores. If significant differences were to exist, it would then be evident that active customers and passive customers would differ from one another in terms of high levels of trust and of commitment.

If active customers are seen as strong relationship customers, they should differ on a large number of items compared to passive customers. The active customers differ significantly on 22 of the 27 measured items, which corresponds to 81.4 per cent. Consequently, it is quite evident that active customers are more relational and passive customers are less relational, which supports Hypotheses 1 and 2. It is clear that many of the differences are also highly significant at the 0.001 level.

Regarding the measured constructs, it is evident that some of the items do not yield significant differences. I will now analyse and comment on the individual constructs and their indicators in order to explain and interpret the difference between the active and the passive customers.

With respect to organisational trust, only two items of five are significant at the 0.001 level, one item at the 0.05 level and two are not significant at all. The three items indicating high levels of trust are related to such indicators as expectations, reliability and confidence that could be interpreted as characterising active customers with relatively strong relationships compared to passive customers with weak relationships.

With respect to commitment, four items of five are significant at the 0.001 level and one is not significant at all. The four items indicating high levels of commitment are related to indicators such as pride and emotions regarded as characterising active customers with relatively strong relationships compared to passive customers.

In terms of future intentions, three items of four are significant at the 0.001 level and one is not significant at all. The three items are all related to such indicators as loyalty and relationship sustainability, which could be interpreted as characterising active customers with relatively strong relationships compared to passive customers.

For brand satisfaction, all three items are significant at the 0.001 level. The three items are all related to indicators such as quality and reliability, which could characterise active customers with strong relationships compared to passive customers.

In terms of brand attitudes, three items are significant at the 0.001 level and two at the 0.05 level. All items relate to indicators associated with different components of the service offering, such as guarantees, fast delivery and satisfactory services as a whole, as well as to the design of photo bags and photo processing services, which could characterise active customers with relatively strong relationships compared to passive customers.

The results also indicate that there are no significance differences between active and passive customers with regard to brand familiarity. A possible explanation might be the lack of interpersonal relationships as well as personal interaction between the company and its customers, a situation that makes it difficult to establish a meaningful personal relationship with the company. It could, however, also be the case that the wrong items were applied in measuring the construct or that too few items were measured.

Finally, the results show that commitment compared to trust seems to be more strongly related to future intentions for active customers with respect to items that yield a high significance of difference to the degree of relational orientation. This could indicate a positive interrelationship among commitment, brand satisfaction and brand attitude in distinguishing active from passive customers.

\section{DISCUSSION AND IMPLICATIONS}

The study presented provides a new perspective on how customer groups might be differentiated in terms of weak or strong relationships in a firm's customer base. It is evident that a firm's customer base can be used for segmentation 
purposes by applying the concepts of trust, commitment and relationships in the managerial application of CRM. Some of the main findings and contributions from this research are considered below.

1. The study provides evidence of the existence of the a priori hypothesised groups of customers within a service provider's customer base, that is, active and passive customers. For this reason, the chosen constructs, as indicators, could be used in differentiating between high and low levels of trust and of commitment.

2. The study shows that these groups of customers differ significantly in terms of their levels of trust and of commitment to the service provider. The results also indicate that active customers seem to be more satisfied and committed than passive customers, having more trust and stronger future intentions as well as more favourable brand attitudes.

3. The study also identifies and highlights the main differences between the two groups of customers in terms of high or low levels of trust and of commitment as a basis for customer segmentation. It allows a firm to distinguish between transactional and relational strategies in developing long-term customer relationships.

The research confirms the existence of differences regarding levels of trust and of commitment between customers with high or low relational orientations. In the present study, the active customers differ significantly with respect to 81 per cent of the measured items compared with 88 per cent from the study of Garbarino and Johnson. Some theoretical implications for the managerial school and marketing strategy will now be discussed.

For some time now, the managerial school has been preoccupied with marketing management, planning and strategy. Marketing management is heavily associated with the development of a marketing mix, which in turn has led to a particular form of marketing strategy. The market segmentation process has been based on mass marketing and concerned largely or even exclusively with identifying market segments.
The results from the current research indicate that in a traditional consumer mass marketing service context, according to the managerial school, there are customer groups with either a high or a low relational orientation that can be depicted on a transactional/relational continuum. In this consumer mass marketing service context, individual customers are not the focus of attention, in contrast to the relationship marketing management school, which emphasises customer and partner relationship management. ${ }^{33}$ The foundation of relationship marketing has been customer-centric, so that it has been seen as a paradigm shift in marketing, in contrast to the seller perspective of marketing, where marketers consider the classic 4P's from a consumeroriented perspective.

The first theoretical implication is the shift from identifying consumer segments to identifying customer groups. In my research, as a basis for analysis, planning and strategy were related to the actual customer base of the company and not the anonymous consumer base in the market. The results support the notion that the only meaningful categorisation of customers is actual behaviour and not potential or speculative behaviour. This conclusion also confirms the importance of defining customers from a customer-centric perspective, in contrast to the perspective of consumers. This has been illustrated by the two-dimensional concept of segmentation.

The second implication is the shift from the consumer as a transactional entity to the customer as a relational entity. In my research, the assumption is that the hypothetical customer groups are defined as active (relational) and passive (transactional). The results confirm that the two customer groups are different in terms of relational orientation with respect to the levels of trust and of commitment.

The third implication is the shift from a goodscentered context to a service-centered context following Vargo and Lusch, ${ }^{4}$ which 'combines tangible products with intangible services' by Jansson. ${ }^{34}$ The research indicates that the service offering of the company consists of the delivered photos - 'the tangible product' - and the 
Table 6: Differences among customer groups

\begin{tabular}{|c|c|c|c|c|}
\hline $\begin{array}{l}\text { Constructs with indicators } \\
\text { (Measurement items) }\end{array}$ & Scale & $\begin{array}{l}\text { Active customers } \\
\text { mean scores } \\
\text { (Standard dev.) }\end{array}$ & $\begin{array}{l}\text { Passive customers } \\
\text { mean scores } \\
\text { (Standard dev.) }\end{array}$ & $\begin{array}{l}\text { Significance of } \\
\text { difference }\end{array}$ \\
\hline \multicolumn{5}{|l|}{ Overall satisfaction } \\
\hline \multirow{3}{*}{ Overall satisfaction } & -3 to +3 & $5.97(1.09)$ & $5.67(1.20)$ & $\star \star \star ~$ \\
\hline & 1 to 7 & $4.94(1.38)$ & $4.73(1.42)$ & * \\
\hline & 1 to 7 & $5.32(1.33)$ & $4.96(1.43)$ & $\star \star \star \star ~$ \\
\hline \multicolumn{5}{|l|}{ Trust } \\
\hline Always meet expectations & 1 to 5 & $4.20(0.83)$ & $4.13(0.86)$ & * \\
\hline Provide good offerings & 1 to 5 & $3.89(0.99)$ & $3.84(0.99)$ & - \\
\hline Reliable and safe & 1 to 5 & $4.40(0.82)$ & $4.29(0.84)$ & $\star \star \star \star$ \\
\hline High confidence & 1 to 5 & $4.33(0.80)$ & $4.18(0.83)$ & $\star \star \star ~$ \\
\hline Rewarding loyal customers & 1 to 5 & $3.93(1.07)$ & $3.95(1.01)$ & - \\
\hline \multicolumn{5}{|l|}{ Commitment } \\
\hline Proud of being customer & 1 to 5 & $3.69(1.06)$ & $3.51(1.12)$ & $\star \star \star ~$ \\
\hline Engage in me as customer & 1 to 5 & $3.79(1.09)$ & $3.68(1.05)$ & - \\
\hline Feel I want to be a customer & 1 to 5 & $4.10(0.95)$ & $3.85(1.02)$ & 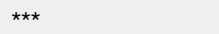 \\
\hline Been a customer many years & 1 to 5 & $3.81(1.24)$ & $3.51(1.29)$ & $\star \star \star ~$ \\
\hline Speak for the company & 1 to 5 & $3.43(1.37)$ & $2.96(1.46)$ & $\star \star \star \star ~$ \\
\hline \multicolumn{5}{|l|}{ Future intentions } \\
\hline Processing in the future & 1 to 5 & $4.21(0.94)$ & $3.85(1.06)$ & $\star \star \star \star$ \\
\hline Negative couldn't go on & 1 to 5 & $3.72(1.24)$ & $3.40(1.31)$ & $\star \star \star ~$ \\
\hline Continue as loyal customer & 1 to 5 & $4.04(1.02)$ & $3.67(1.12)$ & 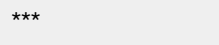 \\
\hline \multicolumn{5}{|l|}{ Brand satisfaction } \\
\hline Satisfaction with the film processing & -3 to +3 & $1.94(1.11)$ & $1.73(1.17)$ & $\star \star \star ~$ \\
\hline High quality of processing & 1 to 5 & $4.27(0.74)$ & $4.19(0.78)$ & $\star \star$ \\
\hline The photo deliveries are safe & 1 to 5 & $4.58(0.68)$ & $4.42(0.79)$ & 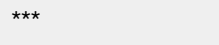 \\
\hline \multicolumn{5}{|l|}{ Brand familiarity } \\
\hline Like personal contacts & 1 to 5 & $3.76(1.17)$ & $3.66(1.18)$ & - \\
\hline Special price offers are essential & 1 to 5 & $3.56(1.17)$ & $3.63(1.18)$ & - \\
\hline \multicolumn{5}{|l|}{ Brand attitudes } \\
\hline Satisfaction with offerings & -3 to +3 & $5.66(1.25)$ & $5.47(1.32)$ & 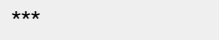 \\
\hline A high valued photo processing & 1 to 5 & $3.92(1.00)$ & $3.81(1.09)$ & * \\
\hline Like design of photo bags & 1 to 5 & $4.18(0.88)$ & $4.10(0.88)$ & * \\
\hline Valuable picture guarantee & 1 to 5 & $4.48(0.78)$ & $4.33(0.82)$ & 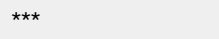 \\
\hline Fast and reliable deliveries & 1 to 5 & $4.50(0.78)$ & $4.30(0.80)$ & $\star \star \star ~$ \\
\hline Continue if good offerings & 1 to 5 & $4.48(0.86)$ & $4.39(0.92)$ & * \\
\hline
\end{tabular}

*Significant difference at the 0.05 level; ${ }^{\star \star}$ significant difference at the 0.01 level; ${ }^{\star \star \star}$ significance at the 0.001 level.

processing - 'the intangible services'. In this case, the products form the basis for service provision.

The main implication of the study is clear support for the notion that a paradigm shift is taking place from the traditional marketing mix to a focus on customers and relationships, or from the managerial school to the relationship marketing management school.

\section{CONCLUSIONS, FUTURE RESEARCH AND LIMITATIONS}

This study is one of the few empirical studies of relationship marketing concepts within a consumer mass marketing context of services. The context entails an indirect interaction between the firm, as a brand, and its customers in terms of nonpersonal relationships compared to interpersonal relationships, where the direct interaction is generally emphasised.

A major conclusion is that in a consumer mass marketing context for services, it is possible to identify customer/supplier relationships related to the concepts of trust and of commitment. It is also evident that, within the customer base of a service firm, it is possible to identify different levels of trust and of commitment between two 
hypothetical groups of customers as a basis for customer segmentation and strategy.

It is evident that customers characterised by strong relationships are highly satisfied and committed, with positive future intentions, while customers with weak relationships are passive, less satisfied and less committed, with less positive future intentions. In terms of relationship sustainability, customers with strong relationships seem to be more loyal partners, while customers with weak relationships seem to be more in the nature of sleeping partners, often referred to as defective customers.

The results of my study conform to those of Pearson and Gessner, ${ }^{35}$ who discuss how a business firm can identify potentially defective customers through what they call 'transactional segmentation'. The authors promote the concept of marketing to individuals rather than groups in using a firm's customer base to develop 'a personal marketing strategy'.

In my study, however, it has been shown that a segmentation approach in a CRM perspective, using the concepts of trust, commitment and relationships, allows a firm to develop and structure existing relationships in new ways. It is evident that active customers are characterised by high levels of trust and of commitment, which means that strong relationships exist over time. Active customers are loyal to the brand, proud of it and have feelings for it. For this reason, a firm should concentrate on developing a brand strategy that reinforces commitment to the brand through emotional, knowledge-based or other experiential elements of personal value to the customer.

On the other hand, it has also been shown that passive customers are characterised by low levels of trust and of commitment, which means weak relationships that come and go from time to time. Passive customers trust the brand but are for certain reasons not so highly committed in terms of loyalty, pride or emotions as active customers. For this reason, a firm should concentrate on developing a brand strategy building and establishing relationships based on elements of personal value that could lead to commitment.

In my study, the analysis gives support for the notion that levels of trust and of commitment exist among active as well as passive customers. But in order to build strong relationships with passive customers, it is obvious that commitment is the crucial factor in terms of a successful brand strategy. For this reason, a commitment-based approach will probably strengthen the relationships with both active as well as passive customers. In this sense, it does not matter what type of customer group, that is, active or passive, a firm should approach with its brand strategy in order to develop and maintain relationships.

The notion here is that organisational trust already exists among both groups of customers. But in order to emphasise relationship development over time, commitment is the critical element of a firm's brand strategy. In this sense, active customers are already highly committed but passive customers are not.

Finally, some of the limitations of the study should be mentioned. The research context is a profit-driven organisation in a service processing industry. It is possible that the generalisations derived from the study on differences among customer groups do not apply to other kind of firms, for example retail and banking organisations. In addition, the study is based on indirect interactions with the firm and its brand in terms of nonpersonal relationships rather than interpersonal relationships as in other studies. Therefore, further research is needed to validate and generalise the results.

Finally, some crucial research questions that should be addressed in future research are: how to convert sleeping partners with weak relationships (passive customers) into strong relationships (active customers) and to determine how firms should differentiate their marketing programmes with regard to customers with strong or weak relationships.

\section{Acknowledgments}

Thanks to Dr Eva Ossiansson, Department of Business Administration, School of Business, Economics and Law Göteborg University, for her assistance with the development of the research design and participation in the data collection process of the empirical study. 


\section{References}

1 El-Ansary, A. I. (2005) 'Relationship marketing management: A school in the history of marketing thought', Journal of Relationship Marketing, Vol. 4, No. 1/2, pp. 43-56.

2 Morgan, R. M. and Hunt, S. D. (1994) 'The commitment-trust theory of relationship marketing', Journal of Marketing, Vol. 58 (July), pp. 20-38.

3 Sheth, J. N. and Parvatiyar, A., (eds.) (2000) 'Handbook of Relationship Marketing', Sage Publications, Thousands Oak, CA.

4 Vargo, S. L. and Lusch, R. F. (2004) 'Evolving to a new dominant logic for marketing', Journal of Marketing, Vol. 68 (January), pp. 1-17.

5 Srivastava, R. K., Shervani, T. A. and Fahey, L. (1999) 'Business processes and shareholder value: An organizationally embedded view of marketing activities and the discipline of marketing, Journal of Marketing, Vol. 63 (October), pp. 168-180.

6 Payne, A. and Frow, P. (2005) 'Strategic framework for customer relationship management', Journal of Marketing, Vol. 69 (October), pp. 167-176.

7 Dibb, S. and Meadows, M. (2004) 'Relationship marketing and CRM: A financial services case study', Journal of Strategic Marketing, Vol. 12, No. 2, pp. 111-125.

8 Ziliani, C. and Bellini, S. (2004) 'Retail micro-marketing strategies and competition', The International Review of Retail, Distribution and Consumer Research, Vol. 14, No. 1, pp. 7-18.

9 Woolf, B. (1996) 'Customer Specific Marketing - The New Power In Retailing', Teal Books, Greenville.

10 Hultén, B. (2003) 'Relational marketing strategy in corporate chains - BCR's customer specific marketing. American Marketing Science AMS Proceedings. American Marketing Science 2003 Annual Conference, Washington DC, May.

11 Alderson, W. (1958) 'The analytical framework for marketing', in Lawrence, R.J. and Thomas, M.J. (eds), 'Modern Marketing Management', Penguin Books Ltd., Middlesex, pp. 58-74.

12 Smith, W. R. (1956) 'Product differentiation and market segmentation as alternative marketing strategies', Journal of Marketing, Vol. XX (July), pp. 3-8.

13 Beane, T. P. and Ennis, D. M. (1987) 'Market segmentation: A review', European Journal of Marketing, Vol. 21, No. 5, pp. 20-42.

14 Doyle, P. (1995) 'Marketing in the new millennium', European Journal of Marketing, Vol. 29, No. 12, pp. 23-41.

15 Gordon, I. H. (1998) 'Relationship Marketing', John Wiley \& Sons, Etobicoke.

16 Oldano, T. L. (1987) 'Relationship segmentation. Enhancing the service provider/client connection', in Surprenant, C. (ed), 'Add Value to Your Service. The Key to Success, Proceedings Series', AMA, Chicago, pp. 143-146.

17 Rigby, D. K., Reichheld, F. F. and Schefter, P. (2002) 'Avoid the four perils of CRM', Harvard Business Review, Vol. 80 (February), pp. 5-11.

18 Verhoef, P. C. (2003) 'Understanding the effects of customer relationship management efforts on customer retention and customer share development', Journal of Marketing, Vol. 67 (October), pp. 30-45.
19 Cao, Y. and Gruca, T. S. (2005) 'Reducing adverse selection through customer relationship management', Journal of Marketing, Vol. 69 (October), pp. 219-229.

20 Bejou, D. and Palmer, A. (1998) 'Service failure and loyalty: An exploratory empirical study of airline customers', Journal of Services Marketing, Vol. 12, No. 1, pp. 7-22.

21 Bruhn, M. (2003) 'Relationship Marketing Management of Customer Relationships', Pearson, Harlow.

22 Gummesson, E. (1999) 'Total Relationship Marketing: Rethinking Marketing Management from 4Ps to 30Rs', Butterworth Heinemann, Oxford.

23 Dwyer, R. F., Schurr, P. H. and Oh, S. (1987) 'Developing buyer-seller relationships', Journal of Marketing, Vol. 51 (April), pp. 11-27.

24 Anderson, J. C. and Narus, J. A. (1991) 'Partnering as a focused market strategy', California Management Review, Vol. 33 (Spring), pp. $95-113$.

25 Brodie, R. J., Coviello, N. E., Brookes, R. W. and Little, V. (1997) 'Towards a paradigm shift in marketing? An examination of current marketing practices', Journal of Marketing Management, Vol. 13, No. 5, pp. 383-406.

26 Berry, L. L. (1995) 'Relationship marketing of services Growing interest, emerging perspectives', Journal of the Academy of Marketing Science, Vol. 23 (Fall), pp. 236-245.

27 Garbarino, E. and Johnson, M. (1999) 'The different roles of satisfaction, trust and commitment in customer relationships', Journal of Marketing, Vol. 63 (April), pp. 70-87.

28 Homburg, C. and Stock, R. M. (2004) 'The link between salespeople's job satisfaction and customer satisfaction in a business-to-business context: A dyadic analysis', Journal of the Academy of Marketing Science, Vol. 32, No. 2, pp. 144-158.

29 Anderson, E., Fornell, C. W. and Lehmann, D. R. (1994) 'Customer satisfaction, market share, and profitability: Findings from Sweden', Journal of Marketing, Vol. 58 (July), pp. 53-66.

30 Jansson, H. (2007) 'International Business Strategy in Emerging Country Markets The Institutional Network Approach', Edward Elgar Publishing, Cheltenham.

31 Gundlach, G. T., Achrol, R. S. and Mentzer, J. T. (1995) 'The structure of commitment in exchange', Journal of Marketing, Vol. 59 (January), pp. 78-92.

32 Zeithaml, V. A., Berry, L. L. and Parasuraman, A. (1996) 'The behavioral consequences of service quality', Journal of Marketing, Vol. 60 (April), pp. 31-46.

33 Parvatiyar, A. and Sheth, J. N. (2001) 'Conceptual framework of customer relationship management', in Sheth, J., Parvatiyar, A. and Shainesh, G. (eds), 'Customer Relationship Management - Emerging Concepts, Tools and Applications', Tata/McGraw-Hill, New Dehli.

34 Jansson, H. (2005) 'From industrial marketing to business-tobusiness marketing and relationship marketing', in Lagrosen, S. and Svensson, G. (eds), 'Marketing: Broadening the Horizons', Studentlitteratur, Lund.

35 Pearson, M. M and Gessner, G. H. (1999) 'Transactional segmentation to slow customer defections', Journal of Marketing Management, Vol. 8, No. 2, pp. 16-23. 